\title{
Ny ultralydteknologi oppdager hjertesjukdom tidligere
}

Asle Hirth, ansatt ved Barneklinikken, Haukeland Universitetssjukehus disputerte torsdag 21. februar 2013 for ph.d.graden ved Universitetet i Bergen med avhandlingen:

\section{Left ventricular systolic deformation in subclinical metabolic cardiomyopa- thies}

Vevsultralyd av hjertet kan oppdage hjertesykdom før en kan se forandringer på tradisjonell ultralyd, og lenge før pasientene med arvelig stoffskiftesykdom eller kronisk nyresykdom fikk symptom på hjertesykdom.

Hjerte- og karsykdom er den hyppigste dødsårsaken hos pasienter med arvelig stoffskiftesykdom eller kronisk nyresykdom. Disse sykdommene påvirker hjertet gjennom ulike prosesser og fører til kardiomyopati. Tradisjonell ultralyd av hjertet oppdager disse skadene relativt sent.
Hovedmålet var å studere om ny ultralydteknologi med såkalt vevsdoppler-teknikk kan påvise skader på et tidligere stadium.

Den første studien undersøkte pasienter i tidlig fase av kronisk nyresykdom. Vevsdoppler av hjertemuskelen oppdaget forandringer som ikke var målbare ved tradisjonell ultralyd.

Den andre studien målte hjertefunksjonen ved tradisjonell- og vevsdoppler-ultralyd hos nyretransplanterte barn og unge voksne. Hos disse pasientene fantes en sammenheng mellom høyt blodtrykk og redusert hjertefunksjon målt ved vevsdoppler-teknikk.

I den tredje studien viste undersøkinger med vevsdoppler-teknikk, at pasienter med stoffskiftesykdommen Fabry hadde redusert hjertefunksjon selv om tradisjonell ultralyd var normal.

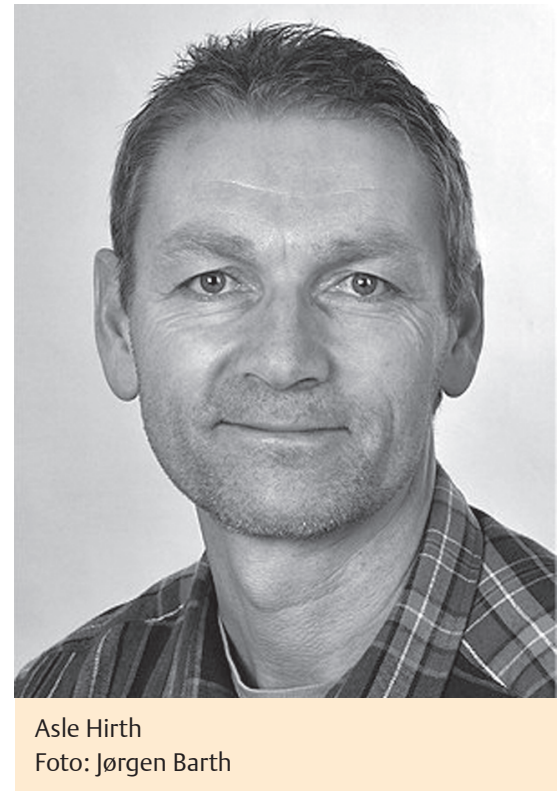

Foto: Jørgen Barth 